\title{
Christina Petterson
}

\section{Chapter 5 \\ New Jerusalem in Greenland: \\ Aspects of Moravian Mission}

Most Moravian settlements were conceptualised according to a square, with the axis either constituted by central buildings or the gaps between the buildings. This architectural pattern has given rise to the assumption that the Moravian settlements are configurations of the New Jerusalem. The present chapter examines the extent to which the idea of New Jerusalem is present in the Moravian mission station of Neuherrnhut in Greenland.

The question of Jerusalem in the early Moravian Brethren is an interesting question because of the community's eschatological fervour, combined with its settlement activities, which saw a flurry of villages and missionary stations constructed in the first half of the eighteenth century. However tempting it may be, to see these building activities as an expression of the "New Jerusalem," we should be very careful in making this connection because there are very few references to Jerusalem in the primary material of the Moravian Brethren. The present study concerns itself with the mission station Neuherrnhut in Greenland, where the Moravians worked as missionaries from 1733 to 1900 (Fig. 5.1).

In the course of their missionary work in Greenland, the Moravians established six missions. The first one was established on the outskirts of the Danish colony of Godthaab (Nuuk), and in 1747 the mission station named Neuherrnhut was inaugurated. In their excellent study of the history of Neuherrnhut from 1733 to 2003, Kathrine and Thorkild Kjærgaard mention that the building was designed on the basis of the New Jerusalem in Revelation 21: 9-27. ${ }^{1}$

In their building activities, the Moravian Brethren materialised the classical Christian idea that the church, the congregation of believers, is an image of the heavenly Jerusalem, so that not only the congregation, but also its constructions anticipate the heavenly city. The fundamental architectonic figure had to be a [cubic] square as in the heavenly Jerusalem, described in detail towards the end of Revelation (21: 9-27). In the shape of a garden or a square [as in a market square] the square is found in the centre of all Moravian building constructions after Herrnhaag. ${ }^{2}$

1 Kathrine Kjærgaard and Thorkild Kjærgaard, Ny Herrnhut i Nuuk 1733-2003 (Nuuk: Ilisimatusarfik, 2003).

2 Kjærgaard and Kjærgaard, Ny Herrnhut i Nuuk 1733-2003, 33. My translation. See also page 34: "the Moravian Brethren's buildings were not only meant to anticipate the heavenly Jerusalem by their architectural basic form, but also by their splendour and size. Also in this case Herrnhaag had showed the way - it was like a residential palace for the king of heaven.”

Christina Petterson, PhD, Independent Scholar, Australian National University, Canberra, Australia 


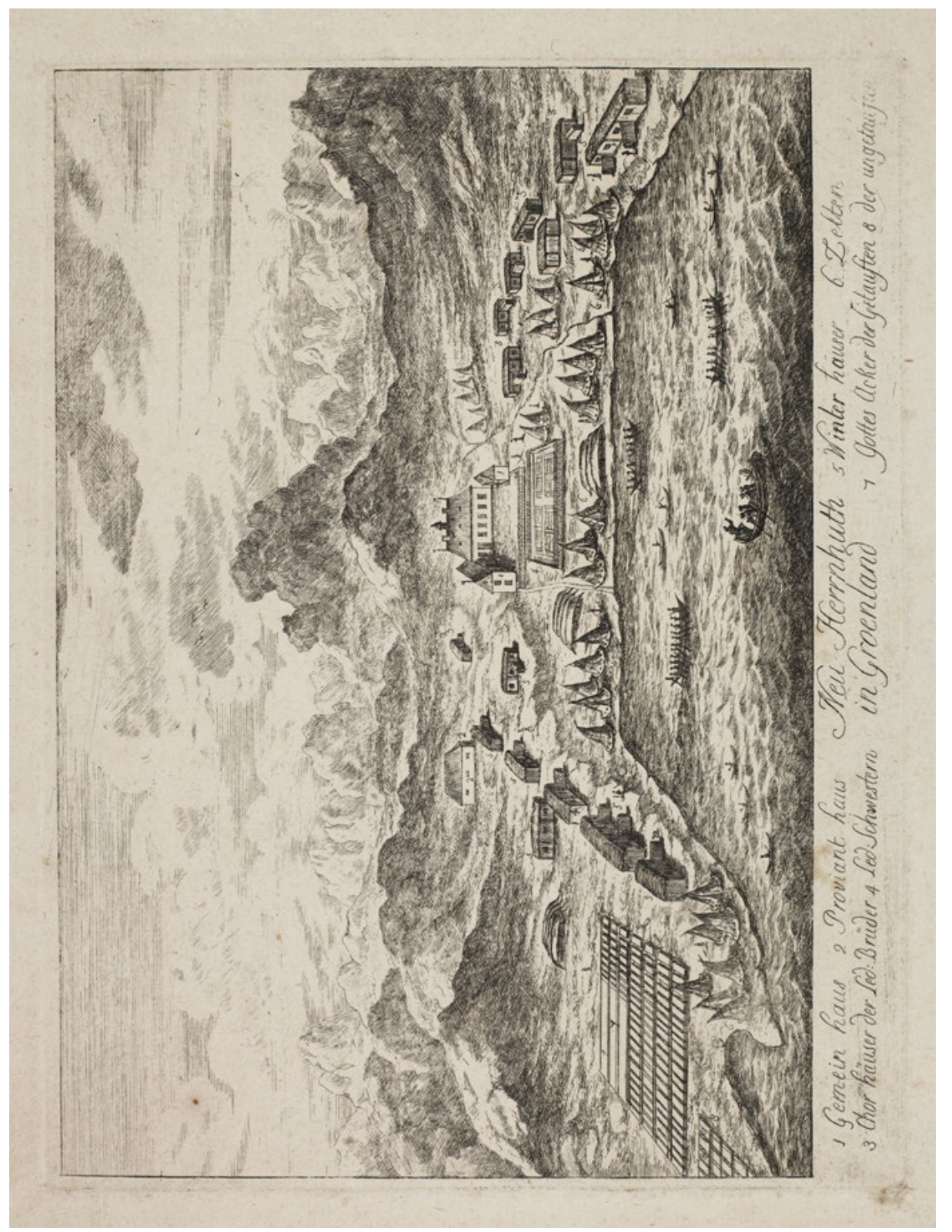

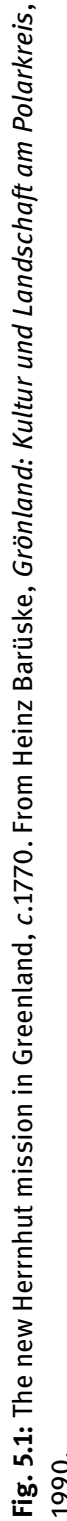


When examining some of the diaries and correspondence from Greenland, however, finding references to Jerusalem in relation to town planning and architecture proves to be very difficult. Apart from one biblical reference, to which I will return, the diaries from Greenland in the first three years and the months surrounding the erection of the buildings make no mention of Jerusalem.

Returning to the argument put forward by Kjærgaard and Kjærgaard we see that they identify Herrnhaag ${ }^{3}$ as the link between Neuherrnhut and Jerusalem. That Herrnhaag was modelled on the New Jerusalem is frequently presupposed. ${ }^{4}$ According to Claus Bernet,

Herrnhaag was originally intended to be a small settlement with exactly twelve buildings in its centre. In a conference in June of 1738 Zinzendorf said the following about the establishment of the centre for the settlement: 'It is not the Saviour's intention that it [Herrnhaag] should extend in a year and a day to twenty-four buildings. Rather every possible effort should be made to hold the number to twelve.' Here Zinzendorf was referring to twelve as the twelve apostles of Jesus, who were symbolized in the plan of Herrnhaag's houses. ${ }^{5}$

When double checking the reference in the minutes of the meeting it says, however:

Herrnhaag: It is not the interest [Sinn] of the Heiland that in time it be expanded to 24 houses, rather one may as far as possible do it so that it comes to around 12, allowed by + [the lot] the orphanage would be useful to build if there is money for it. ${ }^{6}$

There is thus no reference to the apostolic number of 12 as a foundation for the architecture of Herrnhaag, and the number 12 certainly is not an absolute figure in the conceptualisation of Herrnhaag as Bernet seems to suggest. Also, as the plan shows, there were 13 houses in Herrnhaag.

In his architectural analysis of the 19 European Moravian settlements between 1722 and 1808, Andreas Richter shows that there are two main types (and 7 exceptions to either). Type 1, to which Herrnhaag belongs (among others), consists of an empty square (only populated by secondary elements, such as paths, wells, plants, and so forth), around which the community buildings, including the Saal [the Great

3 The settlement of Herrnhaag was founded in 1738 in the Wetterau after Zinzendorf's expulsion from Saxony in 1736, and became the spiritual and executive centre of the community.

4 Klaus Richter, “Aus der Baugeschichte der Herrnhuter Brüdergemeine,” in Herrnhuter Architektur am Rhein und an der Wolga, eds. Reinhard Lahr and Bernd Willscheid (Koblenz: Landskreis Neuwied/Rhein, 2001), 31.

5 Claus Bernet, "The New Jerusalem in the 18th Century among the Moravian Church and the Radical Pietists,” Freikirchen Forschung 16 (2007), 240-1.

6 UA.R.2A.1.3.B, page 4, point 9. "Herrnhaag Es ist nicht des Heylands sxx sinn das es im Jahr und tag auf 24 hauser solte erweitert werden sondern man darff so viel als möglich thun daß es etwa gegen 12 kommen Erlaubt des + das Waisen haus wäre nützlich zu bauen wenn Geld darzu wäre." My translation. UA stands for Unitäts Archiv and refers to material held at the Unity Archives in Herrnhut, Germany. 
Hall] are grouped in threes. Type 2 includes Herrnhut, and has the Saal within the square, dividing the square into two parts that are uneven in respect to size and quality. Here there is no fixed number of houses around the square. ${ }^{7}$

Interestingly, type 1 settlements became standard after the death of Zinzendorf in 1760. At all levels this period saw more centralisation of power and decisionmaking processes to ensure conformity. In relation to settlements and building, a board of building activities was established in 1765, following a building conference in $1763 .^{8}$ In the period before 1760, Herrnhaag and Niesky were the exceptions. Chronologically, Neuherrnhut belongs to the type 2 settlements.

Of even more interest to our present investigation is the fact that Richter analyses the type 1 settlement, i.e. the square with 3 by 3 buildings as equivalent to the 12 gates of the New Jerusalem: the empty square signifies the absence of the temple because of the presence of God and the Lamb. ${ }^{9}$ Richter further speculates (and he is clear that these are just speculations) that this empty space was intended to keep the middle free for the invisible Lord, which he sees as analogous with the decision of the 1741 Synod, which transferred to Jesus the highest office of the Moravian Brethren - the office of General elder - and thus left that space, or office "empty."

However, as mentioned, Herrnhaag is yet another exception to the type 1 in that it does not have 3 by 3 buildings, but 2 by 2 . This means that the Saal does not lie on the axis. Rather, the axis consists of the space between the buildings. ${ }^{10}$ This should at the very least question the seamless connection between Herrnhaag and the New Jerusalem.

\section{Neuherrnhut as Modelled on Herrnhaag}

The building of Neuherrnhut was more than an assembly hall. It had school rooms, residential units, kitchens, storehouses, and so forth. According to Wolf Marx, who has done the most work on the Saals of the Moravians, such multipurpose use of the building was a common feature. Thus, the prayer hall of the first period (1724-1760) was never a building unto itself, but a part of the Gemeinhaus, "the

\footnotetext{
7 Andreas Richter, "Die Siedlungen der Brüdergemeine in Europa. Eine Typologische Übersicht," Unitas Fratrum. Zeitschrift für Geschichte und Gegenwartsfragen der Brüdergemeine 51/52 (2003), 3-5.

8 The Risßbüchlein by Christian Gottlieb Reuter, which connects Herrnhaag with the heavenly Jerusalem was completed in 1760/61. See Ulrike Carstensen, Stadtplanung im Pietismus. Herrnhaag in der Wetterau und die frühe Architectur der Herrnhuter Brüdergemeine (Herrnhut: Herrnhuter Verlag, 2009), 321-33.

9 Richter, "Die Siedlungen der Brüdergemeine in Europa. Eine Typologische Übersicht," 7.

10 Thank you to archivist Olaf Nippe, Unity Archives, Herrnhut, for pointing this out.
} 
community house."11 This is connected, presumably, with the idea that the presence of Christ is within the congregation and not connected to the building. ${ }^{12}$ In the diary entry describing the day of the inauguration, Johannes Beck emphasises the function of the building as a place to "cover us from snow, rain, and where to speak with one another from our hearts and the bloody wounds of the Lamb, and we asked the Lamb for a house where we could hold gatherings." ${ }^{13}$

There is one detail, however, which should be mentioned. First the reference to psalm 84, verse 4 - "The birds have found their tree, the swallows their nest" which is mentioned in the diary on October 16, 1747, when the Moravians inaugurated Neuherrnhut: "Now we can say, now the bird has found its house, and the swallow its nest, a place which the Lamb has chosen on the sea of ice as reward for his pain.”14

This biblical reference is carved on the memorial stone at the site where Christian David cut down the first tree to build the first house in Herrnhut, and he is said to have cited this when cutting. An oddity, in this context, is that the full description of the inauguration of Neuherrnhut is preserved twice: once in the diary written by Christian Stach, which is the one that refers to the psalm, and once in Christian David's description to Zinzendorf. The verse is not mentioned, however, in Christian David's description, which is interesting if he is the one connected with the verse in early Herrnhut.

\section{New Jerusalem or Heavenly Jerusalem: Revelation or Hebrews?}

While Jerusalem, Zion, and the heavenly community are certainly present in the archival material of the Moravian Brethren, there is no evidence for a consistent and fundamental understanding of the Moravian settlements as manifestations of the New Jerusalem.

11 Wolf Marx, Die Saalkirche der Deutschen Brüdergemeine im 18. Jahrhundert (Leipzig: Dieterich'sche Verlagsbuchhandlung, 1931), 9. In Herrnhaag, the Gemeinhaus was inaugurated in 1740, but it quickly became too small, and a new Saal was built as part of Zinzendorf's house. This was completed in 1745. 12 Jørgen Bøytler, "Moravian Values and Moravian Towns," in Christiansfeld Initiative: The Founding Conference 2003 (Christiansfeld, 2003), 11.

13 UA. R.15.J.b.I.1b, October 16, 1747: "ihr wist auch das wir kein plätzgen hatten uns vor schnee, regen, $\mathrm{u}$ kälte $\mathrm{zu}$ verbergen um uns mit einander $\mathrm{zu}$ besprechen vo unsere hertzen $\mathrm{u}$ des Lämleins blutigen wunden, $u$ wir haben das Lamm gebeten um ein Haus wor wir könnten versamlungen halten.” My translation.

14 UA. R.15.J.b.I.1b, October 16, 1747: "Nun können wir sag: Nun hat der Vogel seyn Haus gefunden, $\mathrm{u}$ die Schwalbe ihr Nest, Einer Stätte die sich das Lamm am Eys-Meere vor seinen Schmerzens Lohn erwählet hat . . ..” My translation. 
That is not so say that Jerusalem does not figure in the theological imagery of the Moravians. But rather than the physical creation of a "New Jerusalem" we should rather look to participation in the "heavenly Jerusalem," following the image of Jerusalem in the Letter to the Hebrews (Heb 12:22-25). Of course, in the parlance of the time, as well as in scholarship, this distinction is not always observed. ${ }^{15}$ Nevertheless, this heavenly communion seems to be much more in line with Moravian ideology. The Moravians engaged less with a notion of a New Jerusalem on earth, and more with a transcendentally distinct community with whom they were in direct connection (the upper community), as depicted in the etching of the Moravians worshipping with the upper community and the depiction of the mountain Zion (Fig. 4.1).

In the eighteenth century this was expressed particularly through the musical and liturgical practice of the Moravians, which still has a profound influence on Greenlandic piety today. In a recently published article on Moravian music as praxis pietatis, Church Historian Sven Rune Havsteen analyses the use of music in the description of the inauguration ceremonies of Neuherrnhut, and concludes that music played a significant role in all 5 gatherings which occurred throughout the day. I will mention one, which emphasises the affective nature of music. This is from the third gathering:

At 4, the Greenlandic love feast was summoned [by horns] and with the verse 'when I can eat him etc,' and during the meal many cross air birds and side-hole verses were sung and accompanied by three violins and a flute, the musicians were Br Beyer, Christian David, Molzau, and brother Böhmisch helped with the flute as well as he could, they did the same at the other occasions whenever there was singing in spite of the terrible music, there still was a such a spirit of grace and feeling of love that the Greenlandic members were so drunk that they hardly could leave the Saal, because they had never in their lives seen and heard anything like it. ${ }^{16}$

15 Claus Bernet, "Expectations of Philadelphia and the Heavenly Jerusalem in German Pietism," in A Companion to German Pietism, 1660-1800, ed. Douglas H. Shantz (Leiden: Brill, 2015), 140.

16 UA. R.15.J.b.I.1b, October 16, 1747: “3tens wurde um 4 Uhr zum grönl Liebesmahl geblasen, und mit dem verse wenn ich ihn essen kan etc u unter währendem essen wurden viele † luft vögel und seiten holgen versgel abgesungen $u$ mit drey // violinen $u$ einer Flöte dazu gespilet, die Musicanten waren Br Beyer, C.D. Molzau u br Böhmisch half mit der Flöte so gut er konte, des gleichen Thaten sie auch bey den andere gelegenheiten so oft gesungen wurde, es war doch bei aller der schlechten Music Ein solcher gnaden geist und liebes gefiel daß die grönl geschw ganz trunken waren das sie zu lezt kaum aus dem Saal gehen konten, denn sie hatten den gliechen denige ihr lebtage nicht gesehen und gehört.” My translation. Love feast is a Moravian practice and is a simple and informal gathering of fellows, such as the Greenlandic members, at which food was eaten, prayers given, and hymns sung. Cross air birds was a common name for Moravians in the eighteenth century. It refers to the air blowing from the cross on which the birds can soar. Finally, side hole is another common feature of eighteenth-century Moravian imagery and refers to the wound in Jesus's side from John 19:34. It became a way of referring to Jesus, and was regarded as a place of birth and refuge for the Moravians in the 1740 s and 1750s. 
The way in which music is incorporated in the simple services and gatherings demonstrates that music plays a crucial role in the experience of the unity and divine presence, according to Havsteen. He connects this with the understanding of music as praxis pietatis and considers whether the Moravian use of music was experienced as heavenly music, and as a materialisation of the "social dimension of the divine harmony in the community of the congregation." 17 Thus, the practice of music gave access to the cosmic dimension of which it was a part.

In conclusion, the focus on the Moravian missionary station as a manifestation of the "New Jerusalem" rests on a forced interpretation of the significance of the earthly Jerusalem in Moravian piety. Moravian Christianity at this stage was much more apocalyptic, and thus it could be argued that it was the direct connection with the divine presence which became the heritage of the Moravian missionaries in Greenland. In time, while the Danish state church took over the institutional forms of religious practice and education from around the nineteenth century, the Greenlandic use and appreciation of music as in some way participating in the heavenly choir, and the intimate connection between Greenlanders and Jesus are still very unmediated, and hence, very Moravian.

17 Sven Rune Havsteen, “Musik som praxis pietatis i missionens tid (18.årh.)," i Kristendom $i$ Grønland, ed. Sven Rune Havsteen (København: Eksistensen), 69-75. 
